\title{
PROBLEMATIKA PEMBERDAYAAN DAN PENGEMBANGAN SUMBER DAYA MANUSIA DI SEKOLAH MENENGAH PERTAMA BERBASIS PESANTREN
}

\author{
Desi Eri Kusumaningrum, Raden Bambang Sumarsono, Imam Gunawan \\ Universitas Negeri Malang, Jalan Semarang 5 Malang 65145 \\ Email: desi.eri.fip@um.ac.id
}

\begin{abstract}
The purpose of this research is to describe the problematic of empowerment and human resource development in junior high school based on pesantren in East Java. This research is conducted with qualitative approach. The subjects of this study are school administrative staff (tenaga administrasi sekolah / TAS), teachers, and principals. Data collection techniques are interviews. Subsequently used as material in carrying out focus group discussion (FGD). Data analysis is done through three steps, namely: data reduction; display data; and conclusion drawing / verifying. The results showed that school problems in the empowerment of principals are: the duty of boarding school board; communication barriers and coordination with pesantren; communication barriers with teachers and administrative staff (tenaga administrasi sekolah / TAS); and task delegation. School problems in teacher empowerment are: the ratio of teacherstudent numbers is not proportional; some teachers teach at other educational institutions; lack of understanding how to educate students according to the vision and mission of schools and pesantren; and less optimal teaching supervision. School problems in the empowerment of administrative staff (tenaga administrasi sekolah / TAS) are: the limited infrastructure of the school office; number of TAS personnel; and mastery of information and communication technology (ICT). Human resource development is done in two ways, namely group development and individual development.
\end{abstract}

Keywords: empowerment, development, human resources, schools based pesantren

\begin{abstract}
Abstrak: Tujuan Penelitian ini adalah mendeskripsikan problematika pemberdayaan dan pengembangan sumber daya manusia di sekolah menengah pertama (SMP) berbasis pesantren di Jawa Timur. Penelitian ini dilakukan dengan pendekatan kualitatif. Subjek penelitian ini adalah tenaga administrasi sekolah (TAS), guru, dan kepala sekolah. Teknik pengumpulan data adalah wawancara. Selanjutnya dijadikan bahan dalam melaksanakan focus group discussion (FGD). Analisis data dilakukan melalui tiga langkah, yaitu: data reduction; data display; dan conclusion drawing/verifying. Hasil penelitian menunjukkan bahwa permasalahan sekolah dalam pemberdayaan kepala sekolah adalah: adanya tugas menjadi pengurus pesantren; hambatan komunikasi dan koordinasi dengan pesantren; hambatan komunikasi dengan para guru dan TAS; dan pendelegasian tugas. Permasalahan sekolah dalam pemberdayaan guru adalah: rasio jumlah guru-siswa belum proporsional; beberapa guru mengajar di lembaga pendidikan lain; kurangnya kesepahaman cara mendidik siswa sesuai visi dan misi sekolah dan pesantren; dan kurang optimalnya supervisi pengajaran. Permasalahan sekolah dalam pemberdayaan TAS adalah: terbatasnya sarana prasarana kantor sekolah; jumlah personil TAS; dan penguasaan Teknologi Informasi dan Komunikasi (TIK). Pengembangan sumber daya manusia (SDM) dilakukan dengan dua cara, yaitu pengembangan yang bersifat kelompok dan pengembangan yang bersifat individu.
\end{abstract}

Kata kunci: pemberdayaan, pengembangan, sumber daya manusia, sekolah berbasis pesantren 
Pemberdayaan sumber daya manusia (SDM) diarahkan untuk meningkatkan partisipasi SDM dalam organisasi dan meningkatkan produktivitas. Hasil berbagai studi menunjukkan bahwa SDM merupakan faktor penentu produktivitas. SDM bidang pendidikan tataran sekolah dapat dikelompokkan menjadi tiga, yaitu kepala sekolah, guru, dan staf. Daya saing sekolah juga ditentukan oleh SDM yang dimiliki. Kompetensi SDM menjadi hal yang utama dalam menentukan model pemberdayaan SDM suatu organisasi. Organisasi dengan kompetensi yang bernilai dan langka akan menghasilkan keunggulan bersaing yang lebih besar dibandingkan pesaingnya, yang selanjutnya menghasilkan kinerja yang optimal. Permasalahan yang berkaitan dengan mutu pendidikan bisa diatasi dengan adanya pemberdayaan manusia sebagai subjek dan objek pembangunan. Manusia dapat menunjang keberhasilan pembangunan manakala potensi yang ada pada dirinya dikembangkan dan diberdayakan. Sedangkan manusia yang tidak dapat diberdayakan dan dikembangkan potensinya, akan menjadi beban pembangunan. Kepala sekolah, guru, dan tenaga administrasi sekolah (TAS) merupakan SDM yang ada di sekolah, yang perlu diberdayakan seoptimal mungkin.

SDM dalam bidang pendidikan pada tataran sekolah dapat dikelompokkan menjadi tiga, yaitu kepala sekolah, guru, dan staf. Daya saing sekolah juga ditentukan oleh SDM yang dimiliki. Kompetensi SDM menjadi hal yang utama dalam menentukan model pemberdayaan SDM suatu organisasi. Organisasi dengan kompetensi yang bernilai dan langka akan menghasilkan keunggulan bersaing yang lebih besar dibandingkan pesaingnya, yang selanjutnya menghasilkan kinerja yang optimal. Keunggulan bersaing dan kinerja yang dihasilkan organisasi merupakan konsekuensi dari sumber daya manusia dan kompetensi yang dimiliki (Absah, 2008). Organisasi harus memiliki kemampuan untuk mengkoordinasikan sumber daya strategis dengan baik, sebab merupakan kunci dalam membangun kompetensi dan pada akhirnya pencapaian kinerja yang tinggi.

Kepala sekolah sebagai pemimpin pendidikan memiliki peranan yang krusial dalam memberdayakan semua sumber daya di sekolahnya. Empowerment will moderate the relationship between empowering leadership and creativity (Özarall,
2015). Students change their attitudes regarding their goals from college studies, from being strict to get a certificate to seek knowledge enlargement, know more cultures, gain social and life skills, become empowered and learn about career leadership (Sada-Gerges, 2015). Erkutlu dan Chafra (2015) berdasarkan hasil penelitiannya menyimpulkan bahwa that empowering leadership is positively and significantly correlated with employees' organizational job embeddedness. Pradhani dan Imron (2016) berdasarkan hasil penelitiannya menyimpulkan bahwa peran kepala sekolah sebagai pendidik, manajer, administrator, dan supervisor adalah untuk mengetahui keberhasilan kepala sekolah dalam profesionalisme guru yang melaksanakan pengembangan keprofesian berkelanjutan.

Guru sebagai pembelajar harus dapat membelajarkan siswa. Teachers possess privileged knowledge about the complex realities of teaching (Lefstein dan Perath, 2014). Staf sebagai pelaksana tata usaha sekolah memiliki tugas melaksanakan kegiatan administrasi yang diperlukan di sekolah. Terry (2012) menyebutkan bahwa tenaga administrasi sebagai pekerjaan pelayanan yang mempunyai fungsi memfasilitasi, untuk membantu pekerjaan-pekerjaan pokok berjalan secara efektif dan efisien. Fungsi staf sekolah adalah memberikan pelayanan prima di bidang administrasi sekolah (Usman, 2007). Tujuan penelitian ini adalah untuk mengetahui problematika pemberdayaan dan pengembangan sumber daya manusia di sekolah menengah pertama berbasis pesantren di Provinsi Jawa Timur.

\section{METODE}

Penelitian ini dilakukan dengan pendekatan kualitatif. Subjek penelitian ini adalah tenaga administrasi sekolah (TAS), guru, dan kepala Sekolah Menengah Pertama (SMP) berbasis pesantren di Jawa Timur. Sekolah yang menjadi lokasi penelitian adalah: (1) SMP Assa'adah Gresik, mewakili Jawa Timur bagian utara; (2) SMP Insan Terpadu Probolinggo, mewakili Jawa Timur bagian timur; (3) SMP An Nur Bululawang Malang, mewakili Jawa Timur bagian selatan; dan (4) SMP Mambaul Hisan Kediri, mewakili Jawa Timur bagian barat. Teknik pengumpulan data yang digunakan dalam penelitian ini adalah wawancara. Selanjutnya dijadikan bahan dalam 
melaksanakan focus group discussion (FGD). Analisis data dilakukan melalui tiga langkah, yaitu: (1) reduksi data (data reduction); (2) paparan data (data display); dan (3) penarikan kesimpulan dan verifikasi (conclusion drawing/verifying) (Miles dan Huberman, 1992; Gunawan, 2014).

\section{HASIL}

\section{Permasalahan dalam Memberdayakan Sumber Daya Manusia}

Kepala sekolah sebagai pemimpin pendidikan di sekolah merupakan aktor kunci dalam memberdayakan segenap sumber daya yang ada di sekolah. Kepala sekolah dalam melaksanakan tugasnya sebagai pemimpin pendidikan yang memiliki tugas untuk mengelola SDM di sekolah, memiliki permasalahan tersendiri dalam memberdayakan SDM sekolah. Permasalahan yang dialami oleh kepala sekolah adalah: (1) adanya tugas menjadi pengurus pesantren, selain mengelola sekolah itu sendiri; (2) hambatan komunikasi dan koordinasi dengan Pondok Pesantren; (3) hambatan komunikasi dengan para guru dan TAS; dan (4) pendelegasian tugas.

Kepala sekolah ditunjuk secara langsung oleh pihak Pondok Pesantren. Kepala sekolah memiliki peran ganda dalam lingkungan pendidikan pesantren, yakni sebagai kepala sekolah dan sebagai pengajar di pesantren. Berikut ini adalah cuplikan transkrip wawancara peneliti (P) dengan kepala sekolah (KS).

$\mathrm{P}$ : Masalah-masalah apa yang dihadapi sekolah dalam memberdayakan kepala sekolah?

KS : Kesibukan kepala sekolah mengurus pesantren merupakan sebuah keniscayaan. Pesantren memiliki otoritas untuk mengatur dan memerintah ustadz. Saya hanya menjalankan amanah pesantren. Saya harus bisa membagi waktu antara urusan pesantren dan urusan sekolah. Tak jarang kegiatan pesantren bersamaan dengan kegiatan sekolah. Hal ini mengingat pesantren kami masih relatif kecil. Dengan orang yang masih sedikit, saya harus terlibat dalam urusan pesantren.

Hambatan komunikasi antara kepala sekolah dan pihak pesantren juga dapat terjadi. Komunikasi ini terkait dengan pelaksanaan suatu kegiatan yang dilaksanakan di sekolah. Setiap kegiatan yang akan dilaksanakan oleh sekolah harus sepengetahuan pesantren. Pengembangan sekolah harus mengacu pada visi pesantren. Kepala sekolah dapat mendelegasikan tugasnya kepada Wakil Kepala Sekolah (Wakasek). Pendelegasian tugas ini merupakan wujud nyata upaya sekolah memberdayakan wakasek. Berikut ini adalah cuplikan transkrip wawancara peneliti (P) dengan kepala sekolah (KS) dan staf sekolah (S2).

$\mathrm{P}$ : Masalah-masalah apa yang dihadapi sekolah dalam memberdayakan kepala sekolah?

KS : Kepala sekolah ditunjuk langsung oleh yayasan, sehingga dalam hal ini perlu koordinasi dengan yayasan terkait dengan upaya mengembangkan sekolah. Menyamakan visi pesantren dan sekolah menjadi sebuah keharusan. Sehingga kami harus terus melakukan konsultasi terkait dengan kebijakan sekolah. Semua itu memerlukan waktu.

S2: Kepala sekolah kurang memberi beban tugas kepada wakil.

Peran wakasek sangat strategis untuk membantu tugas kepala sekolah. Kepala sekolah dan Wakasek merupakan satu kesatuan dalam organisasi sekolah. Jalinan komunikasi kepala sekolah dengan guru dan TAS akan mendukung kelancaran sekolah dalam menyelenggarakan organisasi sekolah. Kepala sekolah sebagai manager pendidikan, guru sebagai pendidik, dan TAS sebagai unsur sekolah dalam memberikan layanan administrasi harus bersinergi dalam penyelenggaraan sekolah. Berikut ini adalah cuplikan transkrip wawancara peneliti (P) dengan kepala sekolah (KS).

$P$ : Masalah-masalah apa yang dihadapi sekolah dalam memberdayakan guru?

KS : Kesibukan guru mengajar di lain. Guruguru kami mayoritas berasal dari guru yang sudah pegawai negeri sipil (PNS) di SMP Ngadiluwih. Sehingga kami menganggap beliau-beliau sudah baik dalam hal pengalaman mengajar. Karena hal tersebutlah komunikasi saya dengan para guru kurang berjalan baik, sebab guru sudah merasa berpengalaman, namun terkadang belum sesuai dengan yang dikehendaki oleh pesantren. Sekolah kami masih berupaya untuk mengangkat guru tetap yayasan.

Guru sebagai aktor pendidik yang sering bersinggungan dengan para siswa. Permasalahan sekolah dalam pemberdayaan guru adalah: (1) rasio jumlah guru-siswa belum proporsional, yang berdampak pada beban kerja; (2) beberapa guru 
mengajar di lembaga pendidikan lain, sehingga energi dan waktu belum optimal untuk fokus pada sekolah; (3) kurangnya kesepahaman cara mendidik siswa sesuai visi dan misi sekolah dan pesantren; dan (4) kurang optimalnya supervisi pengajaran. Ujung tombak mutu siswa ditentukan oleh mutu proses pembelajaran yang dirancang dan dilaksanakan oleh guru. Sehingga guru harus memiliki kinerja yang baik dengan didukung oleh beban kerja yang proporsional.

Rasio jumlah guru dan siswa menjadi permasalahan tersendiri yang dihadapi oleh sekolah. Beban mengajar guru yang berlebihan akan mempengaruhi keefektifan proses pembelajarannya, sehingga hal ini berdampak pada ringkat hasil belajar yang dicapai oleh siswa. Pihak pesantren dan sekolah harus memiliki persamaan persepsi terhadap proses pembelajaran yang dilakukan oleh guru dan cara mendidik siswa. Hal tersebut menjadi permasalahan tersendiri dalam penyelenggaraan pendidikan di sekolah. Pelaksanaan supervisi pengajaran yang deprogram sekolah juga dirasa kurang optimal oleh guru. Berikut ini adalah cuplikan transkrip wawancara peneliti (P) dengan kepala sekolah (KS) dan guru (G3).

$\mathrm{P}$ : Masalah-masalah apa yang dihadapi sekolah dalam memberdayakan guru?

KS : Standar jumlah guru dengan siswa belum tercapai. Rasio ini yang membuat beban kerja guru benar-benar harus optimal. Beban mengajar guru-guru kami sangat banyak, sehingga rata-rata semua guru-guru masuk mengajar dalam semua shift. Pembelajaran kami ada dua shift, pagi-sore. Kalau ada guru yang mau masuk pagi saja atau sebaliknya, kami pasti akan menanyakan: Lha yang ngajar sore sopo? (Siapa yang mengajar?).

G3 : Kurangnya kesepahaman cara mendidik anak sesuai visi dan misi sekolah dan pesantren saya rasa. Kami memang mengajar harus sesuai dengan arahan pesantren, namun terkadang kami menafsirkan sendiri maksud dari tujuan pesantren itu seperti apa. Perlu lokakarya sepertinya untuk itu. Supervisi yang dilakukan sekolah juga kurang sepertinya. Selain itu kurangnya keterbukaan informasi pelatihan dan seminar yang diadakan lembaga-lembaga tertentu. Kami terkadang ketinggalan informasi.

Permasalahan beberapa guru mengajar di lembaga pendidikan lain, terjadi di SMP Mambaul
Hisan Kediri. Permasalahan tersebut berdampak pada kurang optimalnya energi dan waktu guru untuk fokus bekerja di sekolah. Permasalahan pemberdayaan guru secara langsung akan mempengaruhi kinerjanya dalam mengajar, dan pada akhirnya akan mempengaruhi hasil belajar siswa. Sekolah dalam hal ini memiliki kebijakan terkait dengan kepegawaian guru, yaitu guru yang masih berstatus PNS tidak dapat menjadi guru tetap yayasan (GTY). Jika seorang guru sudah berstatus GTY, maka ia tidak dibolehkan untuk menjadi GTY di lembaga pendidikan lain, namun boleh mengajar di lembaga lain, dengan diketahui oleh pihak sekolah. Komitmen guru kepada sekolah menjadi hal yang penting dalam penyelenggaraan pendidikan di sekolah.

TAS bertugas mengelola layanan administrasi sekolah kepada segenap warga sekolah dan masyarakat secara umum yang berkepentingan dengan sekolah. Permasalahan sekolah dalam pemberdayaan TAS adalah: (1) terbatasnya sarana prasarana kantor sekolah; (2) jumlah personil TAS; dan (3) penguasaan TIK. Faktor sarana prasarana kantor dalam menunjang layanan pendidikan sekolah merupakan hal yang penting bagi layanan sekolah. Ketersediaan sarana prasarana kantor yang memadahi dan sesuai dengan kebutuhan layanan sekolah dapat meningkatkan keefektifan dan efisiensi layanan sekolah. Evaluasi layanan yang dilaksanakan TAS dilakukan secara kontinu. Berikut ini adalah cuplikan transkrip wawancara peneliti (P) dengan kepala sekolah (KS) dan staf sekolah (S1; S4).

$\mathrm{P}$ : Masalah-masalah apa yang dihadapi sekolah dalam memberdayakan Tenaga Administrasi Sekolah (TAS)?

KS : Terbatasnya tempat dan sarana serta prasarana yang dimiliki, sehingg staf harus terus dioptimalkan pelayanan administrasi kantor guna menunjang penyelenggaraan sekolah

S1: Kurangnya tenaga TAS, dan kurangnya waktu dan kesempatan untuk melakukan evaluasi dan pelatihan terhadap tenaga TAS. Evaluasi layanan TAS dilaksanakan secara insidental, terkadang hanya pada saat adanya layanan yang kurang baru dilakukan evaluasi.

S4 : Kekurangan TAS ketika ada acara mendadak dari sekolah lain. Hal itu yang membuat kami kewalahan bekerja. 
Kemampuan mengoperasikan TIK untuk keperluan kantor sekolah sangat penting untuk menunjang layanan yang diberikan sekolah. Hal ini merupakan masalah tersendiri yang dialami oleh TAS. Kemampuan mengoperasikan komputer merupakan hal mendasar dalam layanan sekolah yang dilaksanakan oleh TAS. Seiring dengan perkembangan TIK, sekolah juga mengalami hambatan. Berikut ini adalah cuplikan transkrip wawancara peneliti (P) dengan staf sekolah (S1).

S1: Kurang ada informasi terkait pelatihan TAS. Penguasaan komputer saya relatif kurang Pak, karena saya masih sebatas mengusai Microsoft Office saja. Aplikasi lain, misalnya terkait dengan sistem informasi saya kurang sekali. Kami sebenarnya memerlukan semacam pelatihan penggunaan sistem informasi yang aplikatif untuk mengelola TU sekolah.

$\mathrm{P}$ : Baik Pak, setidaknya TAS menguasai Microsoft Office untuk keperluan tata usaha sekolah. Dan itu sangat penting.

\section{Bentuk-bentuk Kegiatan untuk Meningkatkan Kompetensi Sumber Daya Manusia}

Berdasarkan hasil wawancara dengan informan (kepala sekolah, guru, dan TAS), bentukbentuk kegiatan untuk meningkatkan kompetensi SDM sekolah dapat dibagi menjadi dua bentuk, yaitu: (1) pengembangan SDM bersifat kelompok; dan (2) pengembangan SDM bersifat individu.

Pengembangan SDM Bersifat Kelompok

Pengembangan kompetensi kepala sekolah yang bersifat kelompok adalah keikursertaannya dalam Musyawarah Kerja Kepala Sekolah (MKKS). Kepala sekolah melalui forum MKKS dapat melakukan diskusi, saling bertukar gagasan, dan dapat menjalin kerjasama antarsekolah yang dipimpinnya. Berikut ini adalah cuplikan transkrip wawancara peneliti (P) dengan kepala sekolah (KS).

P : Bentuk-bentuk kegiatan apa yang dilaksanakan oleh sekolah dalam rangka meningkatkan kompetensi kepala sekolah?

KS : Mengikuti organisasi kepala sekolah (MKKS), dan mengikuti pelatihan. MKKS ini kami lebih fokus pada kepala sekolah yang bertugas di sekolah pesantren Pak. Dalam forum ini kami saling bekerjasama untuk mengembangkan sekolah masing-masing.

Pengembangan kompetensi guru yang bersifat kelompok adalah keaktifan guru dalam forum Musyawarah Guru Mata Pelajaran (MGMP) dan keikutsertaan guru dalam kegiatan lokakarya. MGMP merupakan forum guru berdasarkan mata pelajaran yang diampu, bertujuan untuk meningkatkan kompetensi guru, terutama kompetensi pedagogik. MGMP menjadi wahana guru untuk menyelesaikan masalah-masalah yang dihadapinya, terutama terkait dengan masalah-masalah pembelajaran. Berikut ini ialah cuplikan transkrip wawancara peneliti (P) dengan guru (G10).

$\mathrm{P}$ : Bentuk-bentuk kegiatan apa yang dilaksanakan oleh sekolah dalam rangka meningkatkan kompetensi guru?

G10 : Pengembangan materi pelajaran mencari dari internet dan membaca buku atau majalah; meningkatkan profesi guru dengan membuat karya tulis, penelitian tindakan kelas (PTK), dan mengikuti lomba dibidangnya. Semua itu dapat terwadahi dalam kegiatan MGMP Pak. Kami di MGMP dapat mendiskusikan berbagai hal permasalahan tentang bagaimana kami harus mengajar. Yang menjadi momok bagi guru sekarang adalah tuntutan untuk menulis karya ilmiah itu yang susah Pak.

Pemberlakuan Kurikulum 2013 menjadi tantangan tersendiri bagi sekolah, khususnya guru untuk mampu memenuhi tuntutan yang ada di dalam kurikulum tersebut. Berbagai kegiatan yang diikuti guru merupakan bentuk pemberdayaan guru dalam melaksanakan Kurikulum 2013. Berikut ini ialah cuplikan transkrip wawancara peneliti (P) dengan guru (G1).

$\mathrm{P}$ : Bentuk-bentuk kegiatan apa yang dilaksanakan oleh sekolah dalam rangka meningkatkan kompetensi guru?

G1 : Adanya pelatihan guru ditingkat sekolah, dan pertemuan guru di MGMP. Lokakarya terkait Kurikulum 2013 yang pernah kami ikuti menjadi bekal baik kami untuk melaksanakan kurikulum baru ini. Namun saya rasa masih kurang. Kami masih bingung secaraimplementatifdari Kurikulum 2013. Mulai dari pendekatan pembelajaran sampai dengan bagaimana mengevaluasi. Ada dua cara sepertinya ya Pak? Angka dan deskripsi.

Pengembangan kompetensi TAS yang bersifat kelompok adalah keikutsertaan TAS dalam pelatihan dan kegiatan rutin dalam bentuk diskusi 
dan evaluasi kinerja TAS. Pelatihan tentang ketatausahaan sekolah bagi TAS akan bermanfaat bagi peningkatan kemampuan manajerial TAS. Kinerja TAS dalam memberikan layanan administrasi sekolah, dievaluasi secara kontiny, untuk meningkatkan kepuasan para pelanggan sekolah. Berikut ini ialah cuplikan transkrip wawancara peneliti (P) dengan staf sekolah (S1).

$\mathrm{P}$ : Bentuk-bentuk kegiatan apa yang dilaksanakan oleh sekolah dalam rangka meningkatkan kompetensi TAS?

S1: Rutin melakukan diskusi dan evaluasi kinerja dari TAS. Kami juga diikutkan dalam pelatihan oleh Bapak Kepala Sekolah, dengan memperhatikan jenis pelatihan tersebut, apakah memang benar-benar dapat bermanfaat bagi kami dan layanan ketatausahaan sekolah.

\section{Pengembangan SDM Bersifat Individu}

Pengembangan kompetensi kepala sekolah yang bersifat individu merupakan upaya pribadi kepala sekolah itu sendiri untuk meningkatkan kompetensinya. Pengembangan kompetensi kepala sekolah yang bersifat individu adalah kemampuan kepemimpinan pendidikan dan kemampuan hubungan antarmanusia. Kompetensi yang harus dimiliki oleh kepala sekolah agar ia dapat mengelola sekolahnya dengan baik adalah kepemimpinan. Kepemimpinan kepala sekolah yang baik, akan menjadi faktor yang besar dalam mempengaruhi serta menggerakkan guru dan TAS bekerja seoptimal mungkin demi sekolah berkualitas. Berikut ini adalah cuplikan transkrip wawancara peneliti (P) dengan kepala sekolah (KS).

$\mathrm{P}$ : Bentuk-bentuk kegiatan apa yang dilaksanakan oleh sekolah dalam rangka meningkatkan kompetensi kepala sekolah?

KS : Membaca buku referensi terkait kepemimpinan sekolah; tukar informasi antarsesama kepala sekolah; konsultasi dengan kepala sekolah yang lebih senior. Saya terhitung masih kepala sekolah baru, sehingga dalam forum kepala sekolah, saya banyak mendengar saja, karena untuk proses penyesuaian dan juga sekolah kami relatif baru sehingga harus banyak belajar dulu dari sekolah lain, dengan disesuaikan dari arahan kyai.

Pengembangan kompetensi guru yang bersifat individu adalah: keikutsertaan guru dalam suatu pelatihan, seminar, Uji Kompetensi Guru (UKG), dan menulis karya ilmiah. Kegiatan pelatihan dan/atau seminar yang lazim diikuti guru saat ini adalah pelatihan tentang pelaksanaan Kurikulum 2013 dan pelatihan menulis artikel ilmiah (karya tulis ilmiah / KTI). UKG merupakan ujian untuk mengukur kompetensi dasar tentang bidang studi (sesuai dengan bidang studi sertifikasi guru) dan kemampuan pedagogik seorang guru. Selain itu guru untuk memproses kenaikan pangkat, juga harus memiliki KTI. Guru dituntut untuk terus melakukan upaya meningkatkan kompetensinya. Berikut ini adalah cuplikan transkrip wawancara peneliti (P) dengan guru (G2; G3; G4).

$\mathrm{P}$ : Bentuk-bentuk kegiatan apa yang dilaksanakan oleh sekolah dalam rangka meningkatkan kompetensi guru?

G2 : Kami mengikuti pelatihan dan seminar. Saat ini kami menaruh perhatian penuh untuk melaksanakan Kurikulum 2013, sehingga kami banyak yang diikutkan dalam pelatihan dan seminar tentang Kurikulum 2013. Kami juga melakukan penelitian tindakan kelas. Mencari berbagai materi dari berbagai sumber belajar, seperti perpustakaan, diskusi di persatuan guru, praktikum di laboratorium, menggunakan komputer dan laptop, serta mencari bahan pembelajaran di internet.

G3 : Melalui supervisi yang dilakukan oleh Bapak Kepala Sekolah membantu kami jika ada kesulitan dalam melaksanakan pembelajaran. Saya ikut pelatihan dan dalam seminar juga. Tentu sekolah juga memberi reward jika berprestasi.

G4 : Kami aktif mengikuti MGMP di Kabupaten Malang. Mengikuti diklat atau seminar tentang pendidikan. Mengikuti UKG yang diadakan Diknas.

Pengembangan kompetensi TAS yang bersifat individu adalah: keikutsertaan dalam seminar atau pelatihan laporan dana Bantuan Operasional Sekolah (BOS), seminar Data Pokok Pendidikan (Dapodik), dan program induksi TAS (yang masih kurang paham komputer). Kerja TAS paling banyak menyita waktu adalah administrasi sekolah, mulai dari kepegawaian, keuangan, dan kesiswaan. Perlu kecermatan dalam mengadministrasi semua kegiatan sekolah. Peningkatan kemampuan manajerial TAS, terkait dengan pelaporan keungan sekolah dan dapodik saat ini menjadi fokus sekolah. Sehingga semua TAS dituntut untuk mampu mengoperasikan komputer dan/atau sistem 
informasi manajemen (SIM) guna memperlancar kerjanyanya. Berikut ini adalah cuplikan transkrip wawancara peneliti (P) dengan staf sekolah (S2).

$\mathrm{P}$ : Bentuk-bentuk kegiatan apa yang dilaksanakan oleh sekolah dalam rangka meningkatkan kompetensi TAS?

S2 : Seminar pemanfaatan dana BOS. Laporan BOS memang memerlukan konsentrasi yang tinggi. Kami pernah ikut seminar tentang Dapodik. Selain itu kami juga saling bahu membahu untuk melaksanakan pekerjaan, misalnya ada teman kami yang masih kurang paham komputer, kami selalu membantu.

\section{Optimalisasi Peran dan Perilaku Sumber Daya Manusia}

Permasalahan sekolah dalam memberdayakan SDM yang dimiliki diikuti dengan optimalisasi peran dan perilaku SDM, agar dapat menyelesaikan permasalahan-permasalahan yang ada. Perankepala sebagai pemimpin pendidikan menjadi penentu optimalnya peran yang dimiliki oleh guru dan TAS. Peran kepala sekolah adalah sebagai pemimpin dan motivator bagi semua warga sekolah. Kepala sekolah sebagai pemimpin sekolah dituntut mampu memberikan arah perubahan dan visi sekolah ke depan. Kepala sekolah sebagai motivator yakni dengan selalu memberikan support / energi positif untuk menggerakan guru melakukan tugas secara baik dan bertanggung jawab. Berikut ini adalah cuplikan transkrip wawancara peneliti $(\mathrm{P})$ dengan guru (G2; G6).

$\mathrm{P}$ : Bagaimana peran dan perilaku yang diharapkan dari kepala sekolah dalam rangka optimalisasi pemberdayaan SDM di sekolah?

G2 : Kepala sekolah harus memberikan support / energi positif untuk menggerakkan guru melakukan tugas secara baik dan bertanggung jawab. Kepala sekolah harus selalu me-refresh pengetahuan dan wawasan keilmuannya agar dapat mendukung tugasnya sebagai pemimpin.

G6 : Sebagai seorang pemimpin di sekolah. Seorang pemimpin yang mampu membawa angina perubahan untuk kemajuan sekolah. Pemimpin yang mampu memberikan arahan-arahan dan motivasi pada dewan guru. Kepala sekolah juga sebagai seorang pengawas sekolah, yang melakukan supervisi di kelas. Memberikan solusi terhadap segala masalah-masalah yang dihadapi oleh guru. Itu saya kira yang kami harapkan.

Perilaku yang diharapkan dari kepala sekolah adalah mengoptimalkan pelaksanaan supervisi pengajaran dan selalu belajar untuk meningkatkan pengetahuan serta wawasan keilmuannya tentang kepemimpinan pendidikan. Kepala sekolah memiliki peran sebagai supervisor bagi guru dengan menampilkan perilaku-perilaku positif sesuai dengan nafas pesantren. Perilaku kepala sekolah dalam melaksanakan supervisi pengajaran di sekolah adalah ia sebagai pendengar (listening), solutif (problem solver), dan mampu memberi penguatan kepada guru (reinforcing). Kepala sekolah sebagai seorang pemimpin harus terus belajar tentang bagaimana ia memimpin, sebab sifat hubungan antarmanusia adalah dinamis, sehingga kepala sekolah perlu untuk meningkatkan pengetahuan tentang memimpin. Berikut ini adalah cuplikan transkrip wawancara peneliti $(\mathrm{P})$ dengan guru (G7).

$\mathrm{P}$ : Bagaimana perilaku yang diharapkan dari kepala sekolah dalam rangka optimalisasi pemberdayaan SDM di sekolah?

G7 : Mampu memimpin guru dengan baik terutama, tegas dan mengayomi guru. Mampu melaksanakan supervisi dengan baik kepada guru. Mau mendengar keluhan guru, mampu memberi solusi penyelesaian yang bijak terhadap masalah guru, mau mendukung memberi penguat kepada guru, agar guru merasa nyaman dalam bekerja.

Peran dan perilaku guru adalah ia sebaga pendidik dan pengembang kurikulum. Peran guru sebagai pendidik tak dapat diabaikan dalam sistem pendidikan di sekolah. Guru merupakan orang yang intens berinteraksi dengan para siswa. Sebagai teladan bagi siswanya, guru memiliki peran membentuk karakter siswanya. Guru yang baik akan menjadi role model bagi semua warga sekolah. Perilaku guru menjadi ukuran dalam menentukan kejernihan guru menjadi seorang pendidik. Perilaku guru, baik di kelas dan di luar kelas, akan menjadi contoh siswa dan akan diingat oleh siswa. Peran dan perilaku guru adalah: sebagai pendidik dan sebagai pengembang kurikulum.

Sebagai seorang pendidik, guru memiliki tugas mengembangkan potensi religius dalam diri siswa. Norma dan nilai religi menjadi ruh pendidikan di sekolah. Hal ini selaras dengan nafas pendidikan pesantren. Toleransi dan saling 
menghormati merupakan karakter yang juga penting untuk ditanamkan kepada diri siswa. Berikut ini adalah cuplikan transkrip wawancara peneliti (P) dengan guru (G9; G3).

$\mathrm{P}$ : Bagaimana peran dan perilaku yang diharapkan dari guru dalam rangka optimalisasi pemberdayaan SDM di sekolah?

G9 : Guru berperan sebagai orang tua yakni memberikan wawasan kepada siswa sebagai bekal di masyarakat nantinya. Nilai-nilai religi harus ditanamkan, mengingat fenomena masyarakat saat ini, yang mudah tersulit karena hal-hal sepele. Siswa harus ditanamkan rasa cinta kasih terhadap sesama. Itu sekarang yang penting.

G3 : Mampu menjadi contoh yang baik bagi semua siswa; mampu lebih kreatif dan inovatif dalam setiap pembelajaran.

Guru merupakan pengembang kurikulum yang pertama dalam lingkup sekolah. Setiap kali akan melaksanakan pembelajaran, guru akan merencanakan dengan membuat Rencana Pelaksanaan Pembelajaran (RPP), dengan memperhatikan karakteristik para siswanya. Kedalaman dan keluasan materi yang disampaikan guru adalah faktor utama dalam pembelajaran, agar siswa dapat memahami dan mengaplikasikan pelajaran dalam kehidupan sehari-hari. Berikut ini adalah cuplikan transkrip wawancara peneliti (P) dengan guru (G2; G4).

P : Bagaimana peran dan perilaku yang diharapkan dari guru dalam rangka optimalisasi pemberdayaan SDM di sekolah?

G2 : Guru harus menguasai kurikulum, harus menguasai materi setiap mata pelajaran, guru harus komitmen terhadap pelaksanaan tugas, guru harus disiplin.

G4 : Guru mampu memotivasi siswa, mampu membelajarkan siswa secara efektif. Dinamis dan kreatif mengembangkan proses pembelajaran siswa.

Peranan TAS adalah sebagai orang yang mengelola dan melaksanakan pelayanan administrasi sekolah. Dokumen yang dimiliki oleh sekolah diarsipkan oleh TAS. Peran dan perilaku TAS di sekolah ialah: melakukan pengukuran tentang kualitas layanan pendidikan di sekolah, menyediakan keterangan-keterangan untuk membuat keputusan, dan membantu kelancaran kegiatan administrasi sekolah (kepegawaian, kesiswaan, dan sarana prasarana sekolah). Berikut ini adalah cuplikan transkrip wawancara peneliti (P) dengan kepala sekolah (KS) dan staf sekolah (S2).

$\mathrm{P}$ : Bagaimana peran dan perilaku yang diharapkan dari TAS dalam rangka optimalisasi pemberdayaan SDM di sekolah?

KS : Adanya kontrol dalam memberikan layanan sekolah secara kontinu. Evaluasi kepuasan layanan pendidikan sekolah perlu dikaji oleh TAS dengan cermat. Hasil tersebut untuk bahan evaluasi penyelenggaraan pendidikan di sekolah.

S2: Sebagai seseorang yang mampu membantu melaksanakan informasi yang diperoleh dan menyimpan arsip lembaga. Dokumen-dokumen tersebut akan bermanfaat sebagai bahan data sekolah dalam membuat sebuah kebijakan.

\section{PEMBAHASAN}

Kepala sekolah menjadi aktor penentu dalam memberdayakan SDM di sekolah. Perlu adanya upaya yang masif guna memberdayakan SDM di sekolah. Kepala sekolah sebagai pemimpin pendidikan menjadi krusial dalam memberdayakan SDM di sekolah. Pemimpin pendidikan pada tataran sekolah ialah kepala sekolah (Gunawan, 2016; Sudharta, dkk., 2017; Gunawan, 2017). Empowering leaders can obtain more trust, loyalty, satisfaction and identification from their employees (Amundsen dan Martinsen, 2014; Hon, 2011). Leaders are people who often receive their power through inspiring trust, communicating a vision, focusing on the group process, demonstrating concern for subordinates and the empowering of others (Bennis dan Nanus, 1985; Kouzes dan Posner, 1987; Porter-O'Grady, 1992).

Pemberdayaan kepala sekolah berkaitan dengan bagaimana menciptakan iklim kerja yang baik, pembuatan keputusan, kepercayaan diri, menyediakan fasilitas, dan menjalankan kewenangannya sebagai pemimpin pendidikan di sekolah. Kelima faktor tersebut mempengaruhi penciptaan tempat kerja, kondisi psikologis, komitmen organisasi, dan kehadiran seorang pemimpin. Kepemimpinan dan profesionalisme kepala sekolah menjadi hal yang penting dalam rangka mewujudkan hal tersebut. Keprofesionalan kepala sekolah tercermin dalam sikap dan perilaku sebagai sosok pribadi yang patut digugu dan ditiru, menjadi panutan, dalam pelaksanaan tugas 
kepemimpinan berlandaskan keahlian, baik dalam kemampuan manajerial, kemampuan manajemen, rasa tanggung jawab, loyalitas, rasa kesejawatan, kesetiakawanan, serta kebersamaan sesama warga sekolah (Rakhman, 2012; Gunawan, 2017).

Peran kepala sekolah tak dapat diabaikan dalam meningkatkan hasil belajar peserta didik, karena kepala sekolah memiliki peran membina guru yang profesional dan peserta didik yang berkarakter. Nilai-nilai dan etika kepemimpinan yang ditampilkan kepala sekolah menjadi penentu keberhasilan program pendidikan karakter di sekolah. Leading with values is leading to the heart; leading with moral ethics is leading with humanity (Gunawan, 2015; Gunawan, 2017). Jika ingin peserta didik berkarakter, kepala sekolah dan gurunya dahulu yang harus berkarakter. Guru merupakan teladan bagi para peserta didiknya. Pengembangan karakter peserta didik akan efektif manakala kepala sekolah dan guru bersinergi. Kepala sekolah sebagai pemimpin pendidikan dan guru sebagai manager pembelajaran selalu menampilkan perilaku yang baik.

Guru sebagai pendidik juga menjadi penentu dalam proses mengembangkan potensi peserta didik. Guru merupakan ujung tombak dari mutu pendidikan. Pembelajaran yang dilaksanakan oleh guru pada dasarnya memiliki satu tujuan yaitu mencetak dan mengarahkan siswa supaya jadi orang yang baik, berkepribadian baik, dan cerdas (Gunawan, 2013; Kusumaningrum, dkk., 2016). Guru melalui kegiatan pembelajaran diharapkan menggabungkan keseluruhan potensi otak peserta didik sehingga membentuk kebermaknaan (Gunawan, 2011). The contribution of teachers to student learning and outcomes is widely recognized (Bill and Melinda Gates Foundation, 2010). Guru akan menentukan perilaku siswa yang diajarnya.

Guru adalah orang yang intensitas kegiatannya lebih banyak berhubungan dengan peserta, khususnya dalam proses pembelajaran. Guru dituntut untuk mampu menciptakan pembelajaran yang efektif dan menyenangkan. Guru adalah manajer kelas yang memiliki kewenangan mengelola kelas. A teacher's effectiveness has more impact on student learning than any other factor under the control of school systems, including class size, school size, and the quality of after-school programs (Rivkin, dkk., 2005). Teachers must be convinced that teaching is a profession; many say it is a profession but few believe it; everything must be done to project that image; dress, mannerisms, behavior, and participation in professional activities can enhance their leadership qualities and capabilities (Terry, 2015).

Guru juga memiliki peran dalam membimbing siswa. Guru tidak hanya mempunyai kewajiban mendidik siswa tapi juga mentransterkan ilmu pengetahuannya kepada siswa. Guru lebih banyak memberikan pembelajaran riyadah berupa nasihat dan contoh nyata dalam keseharian, dan apabila dirasakan perlu, guru juga perlu memberikan wejangan dan nasihat pada hari, waktu, dan tempat tertentu (Sumardi, 2012). Jika kepala sekolah dan guru memiliki integritas dan pengetahuan yang kuat, maka akan terwujud peserta didik yang berkarakter dan berkepribadian yang unggul. Ada dua pokok peran strategis sekolah berbasis pesantren, yaitu mencetak kader ulama yang mendalami ilmu agama dan pada saat yang sama mengetahui, terampil, dan peduli terhadap persoalan keummatan (Haningsih, 2008).

TAS sebagai tenaga kependidikan memiliki peran strategis dalam memberikan layanan administratif kepada peserta didik. Aktivitas yang dilaksanakan sekolah, pada dasarnya secara empirik dilaksanakan oleh manajemen perkantoran sekolah. Misalnya dalam manajemen peserta didik, ada ruang lingkup kegiatan membuat buku induk siswa, di sekolah bagian yang membuat buku induk siswa tersebut adalah bagian kantor. Layanan administrasi sekolah dilaksanakan oleh personel yang disebut dengan tenaga administrasi sekolah (TAS). Peranan TAS adalah melaksanakan kegiatan administrasi sekolah dengan memberikan layanan secara optimal. TAS berperan sebagai administrator, dan kepala sekolah, guru, serta siswa yang mendapatkan layanan administrasi tersebut (Usman, 2007). Maisyaroh (2014) menyatakan kelancaran belajar peserta didik sebagian ditentukan oleh mutu layanan tenaga administrasi, sehingga pengembangan staf perlu dilakukan agar dapat melayani peserta didik secara prima.

Staff is not always actively involved in the inception and implementation of change; if behavioral resistance is not identified and worked with, they can reverse even the best-intended change projects; equally, they may resist change 
because it can damage care (Bowers, 2011). TAS di sekolah memiliki peran yang krusial dalam administrasi sekolah. Layanan pendidikan yang diselenggarakan oleh sekolah secara administratif dikelola oleh TAS. TAS yang andal akan memberikan layanan prima (Gunawan dan Benty, 2017).

\section{SIMPULAN}

Permasalahan yang dialami oleh kepala sekolah adalah: (1) adanya tugas menjadi pengurus pesantren, selain mengelola sekolah itu sendiri; (2) hambatan komunikasi dan koordinasi dengan Pondok Pesantren; (3) hambatan komunikasi dengan para guru dan TAS; dan (4) pendelegasian tugas. Permasalahan sekolah dalam pemberdayaan guru adalah: (1) rasio jumlah guru-siswa belum proporsional, yang berdampak pada beban kerja; (2) beberapa guru mengajar di lembaga pendidikan lain, sehingga energi dan waktu belum optimal untuk fokus pada sekolah; (3) kurangnya kesepahaman cara mendidik siswa sesuai visi dan misi sekolah dan pesantren; dan (4) kurang optimalnya supervisi pengajaran. Permasalahan sekolah dalam pemberdayaan TAS adalah: (1) terbatasnya sarana prasarana kantor sekolah; (2) jumlah personil TAS; dan (3) penguasaan TIK.

Guna menyelesaikan masalah pemberdayaan tersebut, sekolah melakukan pengembangan SDM yang bersifat kelompok dan individu. Pengembangan kompetensi kepala sekolah yang bersifat kelompok adalah keikursertaannya dalam MKKS. Pengembangan kompetensi guru yang bersifat kelompok adalah keaktifan guru dalam forum MGMP dan keikutsertaan guru dalam kegiatan lokakarya. Pengembangan kompetensi TAS yang bersifat kelompok adalah keikutsertaan TAS dalam pelatihan dan kegiatan rutin dalam bentuk diskusi dan evaluasi kinerja TAS. Pengembangan kompetensi kepala sekolah yang bersifat individu adalah kemampuan kepemimpinan pendidikan dan kemampuan hubungan antarmanusia. Pengembangan kompetensi guru yang bersifat individu adalah: keikutsertaan guru dalam suatu pelatihan, seminar, UKG, dan menulis karya ilmiah. Pengembangan kompetensi TAS yang bersifat individu adalah: keikutsertaan dalam seminar atau pelatihan laporan dana BOS, seminar Dapodik, dan program induksi TAS (yang masih kurang paham komputer).

\section{UCAPAN TERIMA KASIH}

Terima kasih disampaikan kepada Direktorat Riset dan Pengabdian Masyarakat Direktorat; Jenderal Penguatan Riset dan Pengembangan; Kementerian Riset, Teknologi, dan Pendidikan Tinggi, yang telah mendanai penelitian ini pada Skema Penelitian Produk Terapan Tahun Anggaran 2017. Terima kasih disampaikan kepada Lembaga Penelitian dan Pengabdian kepada Masyarakat (LP2M) Universitas Negeri Malang (UM) yang telah mendukung pelaksanaan penelitian ini. Terima kasih disampaikan kepada Dekan Fakultas Ilmu Pendidikan (FIP) Universitas Negeri Malang (UM) yang telah mendukung pelaksanaan penelitian ini. Terima kasih disampaikan kepada SMP Assa'adah Gresik; SMP Insan Terpadu Probolinggo; SMP An Nur Bululawang Malang; dan SMP Mambaul Hisan Kediri yang bersedia menjadi subyek penelitian ini.

\section{DAFTAR RUJUKAN}

Absah, Y. 2008. Kompetensi: Sumberdaya Pendorong Keunggulan Bersaing Perusahaan. Jurnal Manajemen Bisnis, 1(3), 109-116.

Amundsen, S., dan Martinsen, L. 2014. Empowering Leadership: Construct Clarification, Conceptualization, and Validation of a New Scale. The Leadership Quarterly, 25, 487511.

Bennis, W., dan Nanus, B. 1985. Leaders - The Strategies for Making Change. New York: Harper and Row Publishers.

Bill and Melinda Gates Foundation. 2010. Empowering Effective Teachers: Strategies for Implementing Reforms, (Online), (www. gatesfoundation.org), diakses 13 Maret 2015.

Bowers, B. 2011. Managing ChangebyEmpowering Staff. Nursing Practice Innovation, (Online), 107(32): 19-21, (www.nursingtimes.net), diakses 13 Maret 2015.

Erkutlu, H., dan Chafra, J. 2015. Empowering Leadership and Organizational Job Embeddedness: The Moderating Roles of Task Interdependence and Organizational Politics, (Online), International Conference on Leadership, Technology, Innovation and Business Management, Procedia - Social and Behavioral Sciences, hlm. 3-10, (http://www. 
sciencedirect.com), diakses 13 Oktober 2015. Gunawan, I. 2011. Merekonstruksi Fitrah Pendidikan. Komunikasi, Majalah Kampus Universitas Negeri Malang Tahun 33 Nomor 276 September - Oktober 2011, hlm. 32.

Gunawan, I. 2013. Revitalisasi Karakter Guru menurut Filosofis Jawa: Sebuah Gagasan Mengembangkan Kepribadian Siswa. Proceeding International Seminar on: Local Wisdom and Character Education for Elementary School Students, IKIP PGRI MADIUN, Madiun, 6 April, hlm. 48-62.

Gunawan, I. 2014. Metode Penelitian Kualitatif: Teori dan Praktik. Jakarta: PT Bumi Aksara.

Gunawan, I. 2015. Mengembangkan Kepemimpinan Kepala Sekolah Berbasis Nilai dan Etika. Proceeding National Seminar and International Conference Scientific Forum-Faculty of Education Department of Science Educatioin (FIP-JIP), Fakultas Ilmu Pendidikan Universitas Negeri Gorontalo, Gorontalo, 9 s.d. September 2015, hlm. 302312 .

Gunawan, I. 2016. Merevitalisasi Kepemimpinan Pancasila dalam Bidang Pendidikan. Prosiding Seminar Nasional Penguatan Manajemen Pendidikan di Era Kompetisi Global, Jurusan Administrasi Pendidikan Universitas Negeri Malang, Malang, 12 Maret, hlm. 67-84.

Gunawan, I. 2017. Instructional Leadership Profile of Junior High School's Principal (A Case Study of Junior High School in Malang). International Research-Based Education Journal, 1(1), 64-68.

Gunawan, I., dan Benty, D. D. N. 2017. Manajemen Pendidikan: Suatu Pengantar Praktik. Bandung: Alfabeta.

Haningsih, S. 2008. Peran Strategis Pesantren, Madrasah dan Sekolah Islam di Indonesia. Jurnal Pendidikan Islam El-Tarbawj, 1(1), 27-39.

Hon, A. H. Y. 2011. Enhancing Employee Creativity in the Chinese Context: The Mediating Role of Employee Self-Concordance. International Journal of Hospitality Management, 30, 375384.

Kouzes, J., dan Posner, B. 1987. The Leadership Challenge. San Francisco: Josey-Bass.
Kusumaningrum, D. E., Triwiyanto, T., dan Gunawan, I. 2016. Educational Management of Natural Disaster Response at Lapindo Mudsidoarjo East Java. Journal of Basic and Applied Scientific Research, 6(4), 1-8.

Lefstein, A., dan Perath, H. 2014. Empowering Teacher Voices in an Education Policy Discussion: Paradoxes of Representation. Teaching and Teacher Education, 38, 33-43.

Maisyaroh. 2014. Pengembangan Staf di Lembaga Pendidikan. Manajemen Pendidikan, 24(4), 274-281.

Miles, M. B., dan Huberman, A. M. 1992. Analisis Data KualitatifBuku Sumber tentang MetodeMetode Baru. Terjemahan oleh Tjetjep Rohendi Rohidi. Jakarta: UI Press.

Özarall1, N. 2015. Linking Empowering Leader to Creativity: The Moderating Role of Psychological (Felt) Empowerment, (Online), International Conference on Leadership, Technology and Innovation Management, Procedia - Social and Behavioral Sciences, hlm. 447-454, (http://www.sciencedirect. com), diakses 13 Oktober 2015.

Porter-O'Grady, T. 1992. Transfonnational Leadership in an Age of Chaos. Nursing Administration Quarterly, 17(1), 17-24.

Pradhani, M. W., dan Imron, A. 2016. Peran Kepala Sekolah dalam Pengembangan Keprofesian Berkelanjutan Guru Bersertifikat Pendidik. Manajemen Pendidikan, 25(1), 18-29.

Rakhman, F. 2012. Profesionalitas Kepala SMP Standar Nasional Pondok (Studi Multikasus pada 3 SMP Swasta Standar Nasional). Disertasi tidak diterbitkan. Malang: Program Pascasarjana Universitas Negeri Malang.

Rivkin, S. G., Hanushek, E. A., dan Kain, J. F. 2005. Teachers, Schools, and Academic Achievement. Econometrica, 73(2), 417-458.

Sada-Gerges, W. 2015. College Educational Process: Is it enough for Empowering Students in Dealing with New Leadership Challenges? (Online), International Conference Education, Reflection, Development (ERD 2015), ClujNapoca, Romania, 3 s.d. 4 Juli, Procedia - Social and Behavioral Sciences, hlm. 366376, (http://www.sciencedirect.com), diakses 13 Oktober 2015. 
Sudharta, V. A., Mujiati, M., Rosidah, A., dan Gunawan, I. 2017. Gaya Kepemimpinan Kepala Sekolah dalam Perspektif Psikologi. Jurnal Manajemen dan Supervisi Pendidikan, 2(2), 109-123.

Sumardi, K. 2012. Potret Pendidikan Karakter di Pondok Pesantren. Jurnal Pendidikan Karakter, 2(3), 180-192.
Terry, G. R. 2012. Office Management and Control. Homewood: Richard D. Irwin.

Terry, P. M. 2015. Empowering Teachers as Leaders. National Forum Journals, 1(1), 1-8. Usman, H. 2007. Peranan dan Fungsi Tenaga Administrasi Sekolah/Madrasah dan Upaya Mengefektifkannya. Jurnal Tenaga Kependidikan, 2(22), 13-30. 